Published online: June 5, 2017.

\section{REFERENCES}

1. Shanghai Bund accident caused 35 deaths and 43 people injured [in Chinese]. Sina. http://news.sina.com.cn/c/2015-01-01/061031350815.shtml. Published January 1, 2015. Accessed April 29, 2017.
2. School stampede frequent accidents, what is the biggest blame [in Chinese]. Sohu.com. http://news.sohu.com/20091211/n268873117.shtml. Published December 11, 2009. Accessed April 29, 2017.

3. Burkle FM Jr, Hsu EB. Ram Janki Temple: understanding human stampedes [published online July 23, 2010]. Lancet. 2011;377 (9760):106-107. http://dx.doi.org/10.1016/S0140-6736(10)60442-4.

\title{
Changing Tradition in the Humanitarian Sector: The Business Model Approach of the Kenya Red Cross
}

\author{
Tara Rava Zolnikov, MS, ScM, PhD; Tessa Zolnikov, MPH
}

$\mathrm{G}$ lobal public health issues are increasing and creating consistently elevated humanitarian needs in many countries. For example, the Commission of Africa recommended doubling aid to Africa, and the Sustainable Development Goals suggest contributions reaching the trillions to mobilize and reach new agenda goals. ${ }^{1,2}$ Some specific escalating problematic trends include climate change, reemerging diseases, population growth, and food crises. These worldly challenges pose serious consequences to future populations and infer a need for substantial efforts from humanitarian agencies. Together, the International Committee of the Red Cross (ICRC) and the International Federation of Red Cross and Red Crescent Societies (IFRC), the most established and respected agency aiding in relief to current and future issues, retain a key organizational position for combating longstanding or multiplying public health issues. Although currently available funding addresses existing issues, a new humanitarian model may need to be created to address projected increasing needs. The Kenya Red Cross (KRC) provides a practical model for developing, maintaining, and encouraging additional humanitarian funding in the form of a business-for-profit model.

Two business models of the KRC fit the category of a nonprofit platform supported through business model ventures. The first businesses were 2 hotels, called the The Boma and Boma Inn Hotel. These hotels were the first vision of the KRC to provide additional money for humanitarian causes. The second business is called Emergency-Plus Ambulatory Services. This business is also novel because it was the first ambulatory service in Kenya. Both businesses were innovative ideas that were developed by the KRC to support humanitarian needs across Kenya, but also offer services that were mostly unavailable in Nairobi and Kenya.

The Boma Inn Hotel would prove to be the first successful step for the KRC in their humanitarian-supported business model. Per the 2011 KRC Annual Report, in November of 2009 , hotel operations obtained a US $\$ 16,668,461$ loan from an undesignated bank. ${ }^{3}$ The term loan was established for 10 years, along with an additional overdraft facility of US $\$ 500,000$ for construction expansion of conference facilities. ${ }^{3}$ An additional US $\$ 200,000$ spot-forward operation exchange transaction limit was extended to the hotel by the bank. In July 2011, a second term loan facility of US $\$ 6,952,941$ was obtained by hotel operations; the total loan approved was US $\$ 24,321,402$. $^{3}$ The risk of establishing these large multidimensional business proposals was small; allegedly, incurred expenses could be retained through the direct sale of established assets and property. ${ }^{4}$ Overall, the initial hotel began generating profits 18 months after opening in 2007. This revenue was used to cover approximately $6 \%$ of the KRC's core costs at that time. ${ }^{5}$ The Boma hotels are investment properties that are pledged as collateral on a loan. ${ }^{6}$ Due to heavily investing in these properties, the KRC has decided to switch from ownership to shareholders to pay in full or substantially reduce the loan. ${ }^{6}$ While analyzing the financials, it seems that instead of charging the companies who manage the hotels with the start-up costs of building the hotel along with the cost of the land, the KRC is currently only charging a monthly rent and deferring the repayment of any long-term debt. If the hotels can focus less on debt obligation, then they can run their businesses rather than paying off loans. Thus, additional revenue can go toward expanding the business and utilizing it for the betterment of communities.

Emergency-Plus (E-plus) was created in 2010 by the KRC as a service that had not previously existed on a state-wide level. With an initial fund of US $\$ 800,000,5$ vehicles were purchased and operations commenced; there were 18 vehicles in the original fleet. ${ }^{4}$ Patients had to register with E-plus and pay a yearly fee of US $\$ 30$ to be part of the service; membership was approximately 7800 people in $2011 .^{4}$ Revenue streams to the KRC are derived from membership fees and sales of training courses and first aid kits. After establishing the full capacity of E-plus, the total target revenue from E-plus is 
estimated to be over US $\$ 100,000$ per month; $80 \%$ of profits are expected to be distributed to the KRC's humanitarian requirements and the remaining $20 \%$ are expected to cover administrative and maintenance costs of the company. ${ }^{4}$ Ambulance services have been offered from the KRC since 2010, growing the number of ambulances to 128 and responding to 8577 calls in all regions as well as offering an intensive 4-month paramedic instructors course with paramedic training offered in May $2015 .^{6}$ Moreover, E-plus is currently the largest provider of ambulatory services in Kenya. ${ }^{4}$ E-plus remains unique by choosing to plow back earnings, or reinvesting its profits back into the company for further growth and development; thus, a great potential for continued growth and increased revenue exists.

Some enterprises provide much more than the traditional goods and services offered as a part of their humanitarian mission. ${ }^{5}$ Self-fundraising efforts are important and account for $51 \%$ of revenue raised for non-emergency national society income globally. ${ }^{5}$ The enterprise-based route is one way that humanitarian agencies can procure funding used for relief. This solution was developed and employed by the KRC and shifts the focus from relying on donations, contributions, and grants to creating and promoting self-sustainable businesses that support regional economic growth and development. For example, funding from donors $(28.5 \%)$ and incoming funds being generated $(28 \%)$ are nearly equal in contributions to the income pool used by the KRC for humanitarian relief. ${ }^{4}$ Revenue from KRC businesses provides additional humanitarian assistance to address future issues; thus, this is one way that could be used by other agencies and organizations to approach aid relief in a more systematic and tactical manner.

\section{About the Authors}

National University, Department of Community Health, San Diego, California (Dr Zolnikov), and University of Washington, School of Medicine, Seattle, Washington (Ms Zolnikov).

Correspondence and reprint requests to Tara Rava Zolnikov, National University, Department of Community Health, San Diego, CA, United States (email: tarazolnikov@gmail.com).

Published online: June 8, 2017.

\section{REFERENCES}

1. Moss T, Subramanian A. After the big push: Fiscal and institutional implications of large aid increases. Center for Global Development working paper no. 71. http://ssm.com/abstract=984061. Published October 2005. Accessed June 24, 2012.

2. United Nations. The Sustainable Development Agenda. http://www.un. org/sustainabledevelopment/development-agenda/. Published 2016. Accessed November 28, 2016.

3. Kenya Red Cross. Annual Report 2011. http://www.kenyaredcross.org/ index.php/annual-reports/item/annual-report-2011. Last updated May 27, 2014. Accessed April 30, 2017.

4. Keylock J, Smith K. Kenya Red Cross: Resource Flows and the Humanitarian Contribution. http://www.globalhumanitarianassistance. org/wp-content/uploads/2011/05/Kenya-Red-Cross.pdf. Published May 2011. Accessed September 19, 2012.

5. Doole C. Humanity Inc. http://www.redcross.int/EN/mag/ magazine2012_3/4-9.html. Published 2012. Accessed April 30, 2017.

6. Kenya Red Cross. Annual Report 2014. http://www.kenyaredcross.org/ index.php/annual-reports/item/annual-report-2014. Last updated May 11, 2015. Accessed April 30, 2017.

\title{
Zika Virus and Neurological Disease: Investing in Prevention
}

\author{
Valentina Chiesa, MD; Pietro Ragni, MD
}

$\mathrm{Z}$ ika virus has suddenly evolved into a global pandemic. It was first identified over 50 years ago in Africa and spread to various geographic areas of Asia, the Pacific Islands, and South America, especially Brazil ${ }^{1}$, and it has been at the center of global attention. In Rio de Janeiro, a study prospectively enrolling 88 pregnant women stated that Zika virus infection during pregnancy seems to be associated with fetal death, placental insufficiency, fetal growth restriction, and central nervous system injury. ${ }^{2}$ The outbreak of the virus in French Polynesia was followed by an increased number of central nervous system malformations. ${ }^{3}$ A case-control study conducted in French Polynesia involved 42 patients who developed
Guillain-Barré syndrome (GBS); serological investigations confirmed that all patients had experienced Zika virus infection. $^{4}$

The public consciousness, especially in high-income-counties, is currently alerted on this theme, but do at-risk populations really know how to prevent Zika virus? By asking -in the field-people who contracted the infection or those who traveled in at-risk countries, it seems that Zika virus, as well as its complications, is undervalued.

Efficient and effective interventions at the community level should encompass the following: (1) empowering vulnerable 